\title{
THE COUNTRY SCHOOLMASTER
}

\author{
Sylvia Townsend Warner
}

In 1941 the editor of The Countryman asked a number of people for their thoughts on rural education. This is Sylvia Townsend Warner's response.

The country schoolmaster needs a proper secretary who will carry out all the organizational paper work (ranging from health papers to indents for coal) which at present gets between him and his function of teaching. School managers, one at least, preferably two, should be extra-local. The balance and politics of rural life are such that local school managers, whether of the King Log or King Stork ${ }^{1}$ variety, often get, and retain, their position for reasons that have nothing to do with interest in education. One school manager at least should be a dispassionate outsider. And one father and one mother should be 
included. There is another vital point. There should be faculties (perháps semi-obligatory) whereby teachers themselves can keep up their education. (And, perhaps, they might have more to start off with $^{2}$.) No one can teach reliably who is not also a steady learner. Finally, and crucially, the greatest handicap to rural education is the indifference of parents. While the mass of parents considers the school as a kind of bag into which children can be dropped for the day, education can't come alive.

The Countryman Vol. XXIII, No. 1, April-June 1941, pp.26-7.

1. Aesop's Fables, 'The Frogs Who Asked for a King'. In this tale the frogs asked Jupiter for king and were given a $\log$, which they despised because it was inert. They asked for another king and were given an eel which they also rejected. When they asked a king the third time Jupiter was annoyed by their complaints and sent King Stork which ate the frogs one by one.

2. At the time Warner was writing education for the working class usually meant elementary education only. The school leaving age was fourteen years, but in practice more able children spent the final years of their school repeating lessons already learnt. Traditionally there had been a reliance on the monitorial system in which older children taught younger pupils in return for some teacher training, eventually leading to a teaching qualification. It was hardly a system to encourage high professional standards, and the education attainments of many teachers were often perforce quite rudimentary. (Dunford and Sharp, 1990 pp.1-25)

\section{WORKS CITED}

Aesop's Fables

DUNFORTH, J and SHARP, P. (1990), The Education System in England and Wales. London and New York, Longman. 